\section{Cytotoxicity of Chelating Agents Used In Endodontics and Their Influence on MMPs of Cell Membranes}

Kellin Pivatto ${ }^{10}$, Fabio Luis Miranda Pedro ${ }^{10}$, Orlando Aguirre Guedes ${ }^{1}{ }^{(0)}$, Adriana Fernandes da Silva ${ }^{2}$, Evandro Piva ${ }^{2}$, Thiago Machado Pereira ${ }^{1}$ (D), Welligton Luiz de Oliveira da Rosa $^{2} \mathbb{D}$, Alvaro Henrique Borges ${ }^{1}$ (D)
1Department of Oral Sciences, UNIC - Universidade de Cuabá, Cuiaba, MT, Brazil 2Department of Restorative Dentistry, Biomaterials Development and Control Center, UFPEL Universidade, Pelotas, RS, Brazil

Correspondence: Prof. Dr. Álvaro Henrique Borge, Avenida Manoel José de Arruda, 3100, 78065-900 Cuiabá, MT, Brasil. Tel: +55-65-3363-1264. e-mail: alvarohborges@gmail.com

\begin{abstract}
This study evaluated the cytotoxic effect and the ability to inhibit matrix metalloproteinases (MMP-2 and MMP-9) of $0.2 \%$ chitosan (CH) and 1\% acetic acid (AA) compared with 17\% ethylenediaminetetraacetic acid (EDTA). Cell viability assay was performed according to ISO 10993-5 with mouse fibroblasts (L929). The culture was exposed to $0.2 \% \mathrm{CH}_{1} 1 \% \mathrm{AA}$, and $17 \%$ EDTA. The chelating agents were evaluated immediately after contact with the cells and after $6 \mathrm{~h}, 12 \mathrm{~h}$, and $24 \mathrm{~h}$ of incubation. Cell viability was analyzed using the 3-(4,5-dimethythiazol2-yl)-2,5-diphenyltetrazolium bromide (MTT) assay. Inhibition of the gelatinolytic activity of MMP-2 and MMP-9 was evaluated by gelatin zymography. Different concentrations of $\mathrm{CH}$ were evaluated: $50 \mathrm{mM}, 5 \mathrm{mM}, 0.5 \mathrm{mM}$, and $0.05 \mathrm{mM}$. EDTA $(0.5 \mathrm{mM})$ was used as a positive control. The results demonstrated that $\mathrm{CH}$ and $\mathrm{AA}$ had an initial cytotoxic effect, which decreased after $6 h, 12 h$, and $24 h$, being statistically similar to EDTA $(P>0.05)$. Additionally, $\mathrm{CH}$ at concentrations of $50 \mathrm{mM}, 5 \mathrm{mM}$, and $0.5 \mathrm{mM}$ had an inhibitory effect on MMP-2 and MMP-9, similar to that of the control with EDTA. The chelating agents had no cytotoxic effects after $24 \mathrm{~h}$. MMP-2 and MMP-9 were inhibited by the experimental solutions.
\end{abstract}

\author{
Key Words: chelating \\ agents, chitosan. matrix \\ metalloproteinases, \\ root canal therapy.
}

\section{Introduction}

Chelating agents are claimed to remove the inorganic component of the smear layer from root canal dentin, being commonly used for final irrigation during endodontic treatment (1). The most common chelating agent is ethylenediaminetetraacetic acid (EDTA), which, at neutral $\mathrm{pH}$, reacts with the calcium ions in dentin and forms soluble calcium chelates $(1,2)$. However, if extruded into the periapical tissues, it can cause apoptosis, necrosis (3), inflammation (4), and cytotoxic effects (5). Acetic acid (AA) can remove dentin calcium ions, favoring smear layer removal, but it can also reach the inorganic structure of dentin, causing subsequent erosion and changes in dentin microhardness (6). In order to obtain a chelating effect without harming the dentin content or periapical tissues, other solutions have been proposed and tested, such as chitosan (CH) (7-11).

The chelating effect of $\mathrm{CH}$ is chemically explained by its nitrogen content (6.89\%): nitrogen atoms of amino groups hold free electrons that react with metal cations, leading to the binding of metal cations by chelation (12). In dentistry, $\mathrm{CH}$ has shown antibiofilm (8) and chelating effects (7-10). Its ability to remove the smear layer, similar to that of 17\% EDTA and of calcium hydroxide intracanal medicament, has been confirmed by previous studies $(6,7,9-13)$.

Periapical extrusion of chelating solutions can promote cytotoxic effects (14). Injuries caused to the tissues are enhanced by the effect of the irrigant on the maintenance of cell viability (15). Impairments in cell metabolism and function may be expressed as vascular alterations with activation of inflammatory cells, decrease in proliferative or colony-forming capacity, production of chemical mediators, alteration in macrophage function, necrotic cell death, apoptosis, and degradation of dentin collagen $(3,4,14-17)$. All of these reactions can affect metabolism and cellular repair. Matrix metalloproteinases (MMPs) are zinc-dependent endopeptidases involved in the process of extracellular matrix degradation that occurs both physiologically and pathologically (18). MMP-2 and MMP-9 are present in root dentin and can be inhibited or activated by metal-based restorative materials, dental adhesives, cements, toothpastes, and mouthwashes (19).

Considering the demand for alternatives that are less damaging to the periapical tissues than those currently used (i.e., EDTA), the purpose of this study was to evaluate the cytotoxic effect and the ability to inhibit MMP-2 and MMP-9 of CH and AA compared with EDTA. The null hypothesis tested was that the chelating agents would have non-cytotoxic and inhibitory effects on MMP-2 and MMP-9.

\section{Material and Methods Chelating Agents}

The test solutions were $0.2 \% \mathrm{CH}$ (Chitosan Medical Grade, Sheijiang Chemicals, China), 1\% AA (Merck \& Co 
Inc., St. Louis, MO, USA), and 17\% EDTA (Merck \& Co Inc.). The $0.2 \% \mathrm{CH}$ solution was prepared by diluting $0.2 \mathrm{~g}$ of $\mathrm{CH}$ in $100 \mathrm{~mL}$ of $1 \% \mathrm{AA}$ under magnetic stirring for $2 \mathrm{~h}$ (10).

\section{Cell Culture}

Cells were grown in Dulbecco's modified Eagle's medium (DMEM; Lonza, Basel, Switzerland) supplemented with 10\% fetal bovine serum (FBS), 2\% L-glutamine, penicillin (100 $\mathrm{U} / \mathrm{mL}$ ), and streptomycin (100 $\mathrm{mg} / \mathrm{mL}$ ). Mouse fibroblasts of the $L 929$ immortalized cell line were maintained as a stock culture in DMEM and incubated at $37^{\circ} \mathrm{C}$ in a humidified atmosphere of 5\% CO2 in air until achieving subconfluence. This study was approved by the institutional ethics committee (protocol \#92.078.368).

\section{Cytotoxicity Assay (MTT Assay)}

The cell viability assay was performed according to ISO 10993-5 (2009). The 3-(4,5-dimethylthiazol-2-yl)2,5-diphenyltetrazolium bromide (MTT) assay (Sigma Chemical Company, St. Louis, MO, USA) was used to assess cell metabolic function by mitochondrial dehydrogenase activity. L929 mouse fibroblasts $\left(2 \times 10^{-4}\right.$ cells/well) were maintained in 96-well plates in DMEM for $24 \mathrm{~h}$. Five samples were prepared for each test group. The solutions were filtered with sterilized syringe filters (pore size, $0.22 \mu \mathrm{m}$; Kasvi, São José dos Pinhais, PR, Brazil). After incubation, $200 \mu \mathrm{L}$ of the medium was removed and 200 $\mu \mathrm{L}$ of each test solution was added. During the cytotoxicity assay, one sample containing only fibroblasts in DMEM was used as a negative control. The cytotoxicity of $0.2 \%$ $\mathrm{CH}, 1 \% \mathrm{AA}$, and 17\% EDTA was evaluated as diluted in DMEM. Each well was incubated at $37^{\circ} \mathrm{C}$ for $6 \mathrm{~h}, 12 \mathrm{~h}$, and $24 \mathrm{~h}$ under static conditions. A pilot study demonstrated that $2 \times 104 \mathrm{cell} /$ well was more appropriate to obtain a cell concentration suitable for analysis in time periods of less than $24 \mathrm{~h}(20,21)$.

The test solutions were added and remained in contact with the fibroblasts for $3 \mathrm{~min}$ for $\mathrm{CH}(7,22)$ and $5 \mathrm{~min}$ for EDTA and AA (6). Immediately after this time $(0 \mathrm{~h})$ and after $6 h, 12 h$, and $24 h$ of contact with the cells, the solutions from each well were removed and replaced with $200 \mu \mathrm{L}$ of $\mathrm{MT}$ solution $(5 \mathrm{mg} / \mathrm{mL}$ ). After $4 \mathrm{~h}$ of incubation at $37^{\circ} \mathrm{C}$ in the dark, the MT solution was removed and $200 \mu \mathrm{L}$ of dimethyl sulfoxide (DMSO) was added to each well, and the plates were placed on a shaker for $5 \mathrm{~min}$. Absorbance was determined using a spectrophotometer at a wavelength of $540 \mathrm{~nm}$.

The cell viability (absorbance) data were analyzed using SigmaPlot 12 (Systat Inc., San Jose, CA, USA). Two-way analysis of variance followed by Tukey post hoc test was used for statistical analysis. The level of significance was set at $\mathrm{p}<0.05$.

\section{Zymography}

Proteolytic activity was analyzed on $10 \%$ polyacrylamide gels containing $0.05 \%$ gelatin. The conditioned medium was mixed with an equal volume of non-reducing sample buffer (2\% sodium dodecyl sulfate [SDS]; $125 \mathrm{mM}$ Tris-HCl [pH 6.8], 10\% glycerol, and $0.001 \%$ bromophenol blue) and then electrophoresed.

After electrophoresis at $80 \mathrm{~V}$ for $6 \mathrm{~h}$, the gels were washed twice in 2\% Triton X-100 for $60 \mathrm{~min}$ at room temperature. In order to examine the effect of different concentrations of $\mathrm{CH}$ and $\mathrm{AA}$ on enzyme activity, a conditioned medium containing MMPs was loaded onto preparative gelatin-containing polyacrylamide gels. Gels were cut into strips of approximately $1 \mathrm{~cm}$, and each strip was incubated at $37^{\circ} \mathrm{C}$ for $24 \mathrm{~h}$ in Tris- $\mathrm{CaCl}_{2}$ buffer containing $50 \mathrm{mM}, 5 \mathrm{mM}, 0.5 \mathrm{mM}$, and $0.05 \mathrm{mM}$ of $\mathrm{CH}$. Because $\mathrm{CH}$ was solubilized in $\mathrm{AA}$, an $\mathrm{AA}$ control containing the same concentration used to dilute $\mathrm{CH}$ was used for all $\mathrm{CH}$ concentrations. AA and EDTA $(0.5 \mathrm{mM})$ were used as positive controls, since they are known to be MMP inhibitors (23), while $0.5 \mathrm{mM} \mathrm{N}$-ethylmaleimide (NEM) was used as a non-inhibitory control. The nature of lytic bands observed in the conditioned media was confirmed by performing parallel proteinase inhibition assays. Gelatin-containing gels were incubated in Tris- $\mathrm{CaCl}_{2}$ buffer at $37^{\circ} \mathrm{C}$ for $24 \mathrm{~h}$, with the addition of $0.5 \mathrm{mM}$ EDTA (Reagen, São Paulo, SP, Brazil) to inhibit the lytic activities of MMP-2 and MMP-9.

After the addition of chelators to the solution, the $\mathrm{pH}$ was adjusted to 7.4 and the solution was incubated at $37^{\circ} \mathrm{C}$ for $24 \mathrm{~h}$ in $50 \mathrm{mM}$ Tris- $\mathrm{HCl}$ buffer containing $5 \mathrm{mM} \mathrm{CaCl} 2$ (Tris- $\mathrm{CaCl}_{2}$ ). After incubation, the gels were stained with 0.05\% Coomassie Brilliant Blue G-250. Inhibition of enzyme activity was plotted against the solution concentration. Each assay was performed in triplicate and repeated at least twice.

\section{Results}

$\mathrm{CH}$ had an initially high cytotoxic effect $(0 \mathrm{~h})$, with a cell viability of $13.7 \%$ which was similar to that of AA (11.4\%) and EDTA (8.8\%) (Table 1). The cytotoxic effect of $\mathrm{CH}$ and $\mathrm{AA}$ decreased with time, consistent with the decrease observed in EDTA. At all time points, the viability of $\mathrm{CH}$-treated cells was statistically similar to that of AAtreated cells $(p>0.05)$. At the end of $24 \mathrm{~h}, \mathrm{CH}, \mathrm{AA}$, and EDTA groups were statistically similar $(p>0.05)$ (Table 1).

The results of zymography (Fig. 1) showed that $\mathrm{CH}$ was able to inhibit the gelatinolytic activity of MMP-2 and MMP-9 at concentrations of $50 \mathrm{mM}, 5 \mathrm{mM}$, and $0.5 \mathrm{mM}$, with inhibitory effects similar to those of the respective AA controls. AA and EDTA control groups showed bands of $92 \mathrm{kDa}$ (Pro MMP-9), 77 kDa (Act MMP-9), 72 kDa (Pro MMP-2), and $66 \mathrm{kDa}$ (Act MMP-2) (Fig. 1). 


\section{Discussion}

Based on the results of the present study, the null hypothesis was partially accepted, since both $\mathrm{CH}$ and $\mathrm{AA}$ had a low cytotoxic effect on fibroblasts after $6 h, 12 h$, and $24 \mathrm{~h}$; EDTA, after $12 \mathrm{~h}$ and $24 \mathrm{~h}$. In addition, all chelating agents were able to inhibit MMP-2 and MMP-9. However, the effect of $\mathrm{CH}$ did not differ from that of $\mathrm{AA}$, which is one of the solutions used to solubilize $\mathrm{CH}$ (10). Previous studies have shown that $1 \% \mathrm{AA}$ is ineffective in removing the smear layer, without promoting the demineralization of the dentin walls and differing statistically from the demineralization effect of $0.2 \% \mathrm{CH}(6,7,10)$. In this study, a group with $1 \%$ AA was used to demonstrate the effect of $A A$ on cell viability and to compare it with the effect of $0.2 \% \mathrm{CH}$ solubilized in AA. Although AA presented a higher percentage of cell viability than $\mathrm{CH}$ at $6 h, 12 h$, and $24 h$, there was no statistical difference between them.

Regarding chelating action, $0.2 \% \mathrm{CH}$ and 17\% EDTA solutions are statistically similar in their capacity for chelating ions, removing the smear layer, and reducing dentin microhardness, but these effects are statistically different from the effect of $1 \%$ AA $(6,7,10)$, reason why $0.2 \% \mathrm{CH}$ appears as a promising chelator in endodontic

Table 1 . Cell viability and standard deviation (\%) of the different test groups

\begin{tabular}{lcccc}
\hline Groups & $0 \mathrm{~h}$ & $6 \mathrm{~h}$ & $12 \mathrm{~h}$ & $24 \mathrm{~h}$ \\
\hline EDTA & $8.8 \pm 8.5 \mathrm{~A}, \mathrm{a}$ & $31.6 \pm 11.1 \mathrm{~A}, \mathrm{~b}$ & $79.7 \pm 15.6 \mathrm{~B}, \mathrm{c}$ & $99.5 \pm 4.7 \mathrm{~A}, \mathrm{~d}^{*}$ \\
Chitosan & $13.7 \pm 4.3 \mathrm{~A}, \mathrm{a}$ & $24.8 \pm 8.9 \mathrm{~A}, \mathrm{a}$ & $97.3 \pm 15.7 \mathrm{AB}, \mathrm{b}$ & $100.5 \pm 6.0 \mathrm{~A}, \mathrm{~b}$ \\
Acetic acid & $11.4 \pm 4.0 \mathrm{~A}, \mathrm{a}$ & $43.7 \pm 12.0 \mathrm{~A}, \mathrm{~b}$ & $98.3 \pm 7.6 \mathrm{~A}, \mathrm{c}$ & $103.4 \pm 6.7 \mathrm{~A}, \mathrm{c}$ \\
\hline
\end{tabular}

*Different lowercase letters in the same row and different uppercase letters in the same column indicate statistically significant differences $(p<0.05)$. treatment. The chelating agents were tested at clinically used concentrations: $1 \% \mathrm{AA}, 0.2 \% \mathrm{CH}$, and $17 \%$ EDTA. Cell viability assay evaluates cytotoxic effects by measuring the behavior of cell cultures against a given substance and may be indicative of effects caused in vivo, although its results cannot be directly extrapolated to the in vivo condition (5). Different time points were used to mimic the effect of the chelating agents immediately after contact with the cells and the effect of residual components over time.

$\mathrm{CH}$ had no cytotoxic effect on fibroblasts at $24 \mathrm{~h}$. The cell viability of $\mathrm{CH}$ increased from $13.7 \%$ at baseline $(0 \mathrm{~h})$ to $100 \%$ after $24 \mathrm{~h}$, with a value similar to those of $17 \%$ EDTA (99.5\%) and 1\% AA (103.4\%). AA had the highest percentage of cell viability compared with the other test solutions during the experiment, with the initial cytotoxic effect also being reversed at $24 \mathrm{~h}$. An increase in the number of viable cells depends on a number of factors, such as nutritional reserve, ability to disperse the substances within the medium, adaptation of the cells to the medium, and the difference in the cytotoxic effect of each substance. Furthermore, phagocytic cells and lymph and blood vessels help to dilute and carry away the drug in the body (15). In the present study, the self-renewal capacity of the cells provided support for a non-cytotoxic effect of all test solutions after the 24-h interval.

The 17\% EDTA solution had a cell viability lower than $30 \%$ at baseline $(0 \mathrm{~h})$, indicating an initial cytotoxic effect, which was reversed at $24 \mathrm{~h}$, in agreement with a previous study (24). The result obtained here at $24 \mathrm{~h}$ with

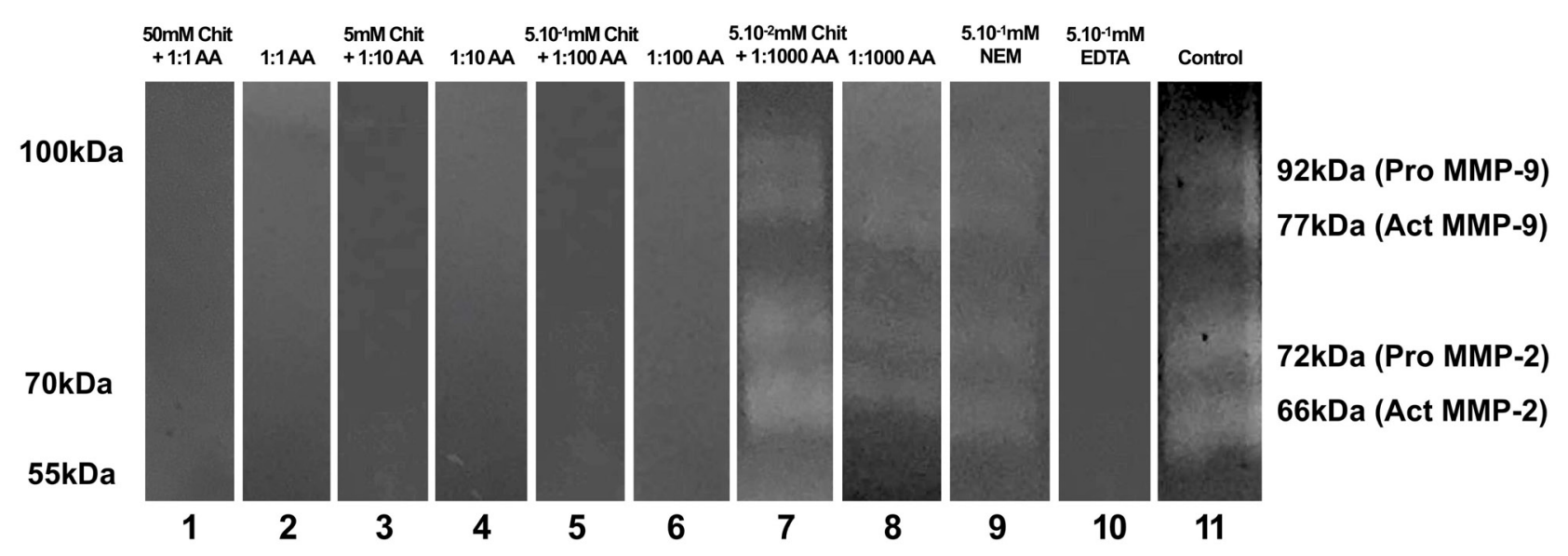

Figure 1: Results of MMP-2 and MMP-9 inhibition by chelating agents as determined by gelatin zymography. Gelatinolytic activities of MMP-2 and MMP-9 were detected by electrophoresis in gelatin containing 10\% polyacrylamide gel. Ethylenediaminetetraacetic acid (EDTA; $0.5 \mathrm{mM}$ ), a known MMP inhibitor, was used as a positive control, while N-ethylmaleimide (NEM; $0.5 \mathrm{mM}$ ) was used as a non-inhibitory control. Chitosan (CH) solution was prepared by diluting $\mathrm{CH}$ in acetic acid (AA), and an AA control containing the same concentration used to dilute $\mathrm{CH}$ was therefore used for all CH concentrations. The control shows bands of 66 and $72 \mathrm{kDa}$, related to Act MMP-2 and Pro MMP-2, respectively, and of 77 and $92 \mathrm{kDa}$ for Act MMP-9 and Pro MMP-9, respectively. Lysis zones indicate the activity of MMPs in the digestion of gelatin. The absence of lysis zones indicates MMP inhibition by the chelators. 
$17 \%$ EDTA, diluted to $0.1 \%$, was also consistent with the cell viability of $87 \%$ reported in that same study at $24 \mathrm{~h}$ (24). However, with EDTA diluted to $0.5 \%$, the results were conflicting (16). In addition, our result was contrary to that of other investigators who concluded that the cytotoxic effect of $15 \%$ and $17 \%$ EDTA is time- and dose-dependent $(3,5,14,15,17,25)$. These conflicting results may be explained by the use of a variety of methods other than the MT assay used in the present study to evaluate the cytotoxic potential of chelating agents (25). Another methodological difference is the use of macrophages and non-fibroblast cells to evaluate cytotoxic effects (14). In the present study, the ISO 10993-5 standard was followed, which recommends the use of fibroblasts for cytotoxicity testing.

The results obtained by zymography defined the clinically used chelating agents as inhibitors of MMP-2 and MMP-9. Gelatinases A (MMP-2) and B (MMP-9) are involved in the processes of cell migration and re-epithelialization. According to a study in a rat model, MMP-2 stimulates epithelial cell migration, while MMP-9 stimulates healing by promoting the migration of several cell types (18). MMP-2 and MMP-9 identified in root dentin are part of a family of more than 20 MMPs (18). They are categorized according to their structure and substrate specificity into collagenases, gelatinases, membrane type (MT-MMPs), stromelysins, and matrilysins $(18,19)$. Like the other MMPs, MMP-2 and MMP-9 play a role in cell invasion, cartilage degradation, tissue remodeling, wound healing, and embryogenesis (18) and are also present in pathological processes, such as rheumatoid arthritis, cancer, obstructive pulmonary disease, and periodontal inflammation, among others $(18,19)$

$\mathrm{CH}$, with different molecular weights, has been shown to inhibit MMP-2 in gingival fibroblasts when evaluated by zymography (26). This suggests that the inhibitory capacity of $\mathrm{CH}$ is related to its proven ability to inhibit zinc, supporting its commercial use as a chelator (26). This is consistent with the present study in which $\mathrm{CH}$ at concentrations of $50 \mathrm{mM}, 5 \mathrm{mM}$, and $5.10-1 \mathrm{mM}$ had an inhibitory effect on MMP-2 activity in $L 929$ mouse fibroblasts assessed by zymography. EDTA was used as a parameter for comparison in zymography, providing the minimum inhibitory concentration values for a chelating agent (23). Also, our results showed that $\mathrm{CH}$ had an inhibitory effect similar to that of AA, which was used as a solubilizing agent to prepare the $\mathrm{CH}$ solution. One can speculate that the inhibitory effect of $\mathrm{CH}$ on MMP-2 and MMP-9 may be mediated by the AA present in the $\mathrm{CH}$ solution, a hypothesis that needs to be further investigated.

Most MMPs are secreted as latent precursors (zymogens) or inactive enzymes that remain anchored to the cell surface, limiting their catalytic activity to membrane proteins or proteins within the secretory pathways or extracellular space (18). The structural catalytic domain of MMPs contains three histidines that bind to $\mathrm{Zn2+}$ sites and one that binds to a water molecule, with the cysteine-thiol-zinc linkage maintaining the MMPs in a latent form (18). Some MMPs, such as MMP-2, MMP-19, MMP-28, and some MT-MMPs, play an important role in homeostasis and are expressed in normal tissues. However, most MMPs remain latent, being expressed only when they are activated for repair, for remodeling or in diseased or inflamed tissues (18).

The ability of metal salts, such as $\mathrm{ZnSO}_{4}$, CuSO4, $\mathrm{HgSO} 4$, and $\mathrm{SnCl} 2$, to inhibit MMP-2 and MMP-9 justifies the classification of these enzymes as zinc-dependent $(2,18,19)$. Although not fully understood, the relationship between the accumulation of metals in connective tissue and their interference with the formation or resorption of extracellular matrix components has already been proven $(18,19)$. The ability of EDTA, CH, and AA to remove calcium, potassium, magnesium, sodium, sulfur, and zinc phosphate from root dentin may be governed by their metal-related mechanisms of action, i.e., through adsorption, ion exchange, and chelation $(7,10,26,27)$. These interactions vary according to the binding ion, the chemical structure of $\mathrm{CH}$, and the $\mathrm{pH}$ of the solution $(7,8,27)$. Two models may explain the chelation process of $\mathrm{CH}$. One of them, known as the bridge model, is based on the theory that two or more amino groups of a $\mathrm{CH}$ chain bind to the same metal ion $(7,8,27)$. The other model is based on the theory that only one amino group of $\mathrm{CH}$ participates in the binding, and the metal ion is anchored to the amino group $(7,8,27)$. The adsorption capacity of $\mathrm{CH}$ is influenced by the amount of free amino groups and by the hydrophilicity of the adsorbed molecules (27).

It is necessary to consider that the present study is an in vitro evaluation. Despite following the same steps used in clinical practice, the results cannot be extrapolated in vivo, but they may serve as reference data for future evaluations. It is important to note that the results of this study are limited to the cells and enzymes evaluated here, and further studies involving other cell types and biological properties of $\mathrm{CH}$ are still required. Therefore, the perspective that a new chelating agent has potential for use in endodontic treatment demands elucidation of its mechanisms of action and effects when in contact with the periapical tissues, aiming to ensure safety in its application.

In conclusion, $\mathrm{CH}$ had a cytotoxic effect similar to that of EDTA immediately after contact with fibroblast cells, which decreased after $6 h, 12 h$, and $24 \mathrm{~h}$ of incubation. In addition, $\mathrm{CH}$ had an inhibitory effect on MMP-2 and MMP-9 similar to that of EDTA. 


\section{Resumo}

Este estudo avaliou o efeito citotóxico e a capacidade de inibição das metaloproteinases da matriz extracelular (MMP-2 e MMP-9) pela quitosana $0,2 \%(\mathrm{CH})$ e o ácido acético 1\% (AA) em comparação com o ácido etilenodiaminotetracético 17\% (EDTA). 0 ensaio de viabilidade celular foi realizado de acordo com a ISO 10993-5 com fibroblastos de camundongo (L929). A cultura foi exposta a CH 0,2\%, AA 1\% e EDTA 17\%. Os agentes quelantes foram avaliados imediatamente após o contato com as células e após 6 h, 12 h e $24 \mathrm{~h}$ de incubação. A viabilidade celular foi analisada utilizando o ensaio de brometo de 3- (4,5-dimetitiazol-2-il) -2,5-difeniltetrazólio (MTT). A inibição da atividade gelatinolítica de MMP-2 e MMP-9 foi avaliada por zimografia de gelatina. Diferentes concentrações de $\mathrm{CH}$ foram avaliadas: $50 \mathrm{mM}, 5 \mathrm{mM}, 0,5 \mathrm{mM}$ e 0,05 $\mathrm{mM}$. EDTA $(0,5 \mathrm{mM})$ foi usado como controlo positivo. Os resultados demonstraram que $\mathrm{CH}$ e $\mathrm{AA}$ apresentaram um efeito citotóxico inicial, que diminuiu após $6 h, 12 \mathrm{~h}$ e $24 \mathrm{~h}$, sendo estatisticamente similar ao EDTA $(P>0,05)$. Adicionalmente, $\mathrm{CH}$ a concentrações de $50 \mathrm{mM}, 5 \mathrm{mM}$ e $0,5 \mathrm{mM}$ tiveram um efeito inibidor sobre MMP-2 e MMP-9, semelhante ao controlo com EDTA. Os agentes quelantes apresentaram efeitos não citotóxicos após $24 \mathrm{~h}$. MMP-2 e MMP-9 foram inibidas pelas soluções experimentais.

\section{References}

1. Machado R, Garcia LDFR, da Silva Neto UX, Cruz-Filho AMD, Vansan LP. Evaluation of 17\% EDTA and 10\% citric acid in smear layer removal and tubular dentin sealer penetration. Microsc Res Tech 2018;81:275-282.

2. Ulusoy ÖI, Savur IG, Alaçam T, Çelik B. The effectiveness of various irrigation protocols on organic tissue removal from simulated internal resorption defects. Int Endod J 2018; 9:1030-1036.

3. Ballal NV, Rao BN, Mala K, Bhat KS, Rao BS. Assessment of genotoxic effect of maleic acid and EDTA: a comparative in vitro experimental study. Clin Oral Investig 2013;17:1319-1327.

4. Zacarro Scelza MF, da Silva Pierro VS, Chagas MA, da Silva LE, Scelza P. Evaluation of inflammatory response of EDTA, EDTA-T, and citric acid in animal model. J Endod 2010;36:515-519.

5. Vouzara T, Koulaouzidou E, Ziouti F, Economides N. Combined and independent cytotoxicity of sodium hypochlorite, ethylenediaminetetraacetic acid and chlorhexidine. Int Endod J 2016;49:764-773.

6. Pimenta, JA, Zaparolli D, Pécora JD, Cruz-Filho AM. Chitosan: effect of a new chelating agent on the microhardness of root dentin. Braz. Dent. J., 2012;3:212-217.

7. Silva PV, Guedes DF, Nakadi FV, Pécora JD, Cruz-Filho AM. Chitosan: a new solution for removal of smear layer after root canal instrumentation. Int Endod J 2013;46:332-338.

8. Del Carpio-Perochena A, Bramante CM, Duarte MA, de Moura MR, Aouada FA, Kishen A. Chelating and antibacterial properties of chitosan nanoparticles on dentin. Restor Dent Endod 2015;40:195-201.

9. Mathew SP, Pai VS, Usha G, Nadug RR. Comparative evaluation of smear layer removal by chitosan and ethylenediaminetetraacetic acid when used as irrigant and its effect on root dentine: An in vitro atomic force microscopic and energy-dispersive $\mathrm{X}$-ray analysis. J Conserv Dent 2017;20:245-250.

10. da Silva Mira PC, Souza-Flamini LE, da Costa Guedes DF, Da CruzFilho AM. Evaluation of the chelating effect of chitosan solubilized in different acids. J Conserv Dent 2017;20:297-301.

11. Aydin ZU, Özyürek T, Keskin B, Baran T. Effect of chitosan nanoparticle,
QMix, and EDTA on TotalFill BC sealers' dentinal tubule penetration: a confocal laser scanning microscopy study. Odontology 2018 Apr. 12. [Epub ahead of print DOI: 10.1007/ s10266-018-0359-0].

12. Li CB, Hein S, Wang K. Biosorption of chitin and chitosan. Mater Sci Tech-lond 2008;24:1088-1099.

13. Raghu R, Pradeep G, Shetty A, Gautham PM, Reddy TVS. Retrievability of calcium hydroxide intracanal medicament with three calcium chelators, ethylenediaminetetraacetic acid, citric acid, and chitosan from root canals: An in vitro cone beam computed tomography volumetric analysis. J Conserv Dent 2017;20:25-29.

14. Amaral KF, Rogero MM, Fock RA, et al. Cytotoxicity analysis of EDTA and citric acid applied on murine resident macrophages culture. Int Endod J 2007;40:338-343.

15. Ballal NV, Kundabala M, Bhat $S$, Rao N, Rao BS. A comparative in vitro evaluation of cytotoxic effects of EDTA and maleic acid: root canal irrigants. Oral Surg Oral Med Oral Pathol Oral Radiol Endod 2009; 108:633-638

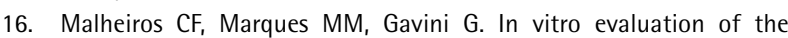
cytotoxic effects of acid solutions used as canal irrigants. J Endod 2005;31:746-748.

17. Marins JS, Sassone LM, Fidel SR, Ribeiro DA. In vitro genotoxicity and cytotoxicity in murine fibroblasts exposed to EDTA, NaOCl, MTAD and citric acid. Braz Dent J 2012;23:527-533.

18. Am区linei C, C邓runtuID, B囚lan RA. Biology of metalloproteinases. Rom J Morphol Embryol 2007;48:23-34.

19. de Souza AP, Gerlach RF, Line SRP. Inhibition of human gingival gelatinases (MMP-2 and MMP-9) by metal salts. Dent Mater 2000;16:103-108.

20. Moreira AG, Cuevas-Suárez CE, da Rosa WLO, Ogliari AO, Petzhold CL, Piva $E, 0$ gliari FA, Lima GDS. Piperonyl methacrylate: Copolymerizable coinitiator foradhesive compositions. J Dent. 2018 Dec;79:31-38.

21. Rossato TCA, Gallas JA, da Rosa WLO, da Silva AF, Piva E, Peralta SL, Lund RG. Experimental Sealers Containing Metal Methacrylates: Physical and Biological Properties. J Endod. 2017 Oct;43(10):1725-1729.

22. Silva, PV, Guedes DF, Pécora JD, da Cruz-Filho AM. Time-dependent effects of chitosan on dentin structures. Braz. Dent. J., 2012, vol.23, no.4, p.357-361. ISSN 0103-6440.

23. Henn $S$, de Carvalho RV, Ogliari FA, de Souza AP, Line $S R$, da Silva AF et al. Addition of zinc methacrylate in dental polymers: MMP-2 inhibition and ultimate tensile strength evaluation. Clin Oral Investig 2012;16:531-536.

24. Prado M, Silva EJ, Duque TM, Zaia AA, Ferraz CC, Almeida JF et al. Antimicrobial and cytotoxic effect of phosphoric acid solution compared to other root canal irrigants. J Appl Oral Sci 2015;23:158163.

25. Koulaouzidou EA, Margelos J, Beltes P, Kortsaris AH. Cytotoxic effects of different concentrations of neutral and alkaline EDTA solutions used as root canal irrigants. J Endod 1999;25:21-23.

26. Kim MM, Kim SK. Chitooligosaccharides inhibit activation and expression of matrix metalloproteinase- 2 in human dermal fibroblasts. FEBS Lett 2006;580:2661-2666.

27. Sobahi TRA, Abdelaal MY, Makki MSI. Chemical modification of chitosan form metal ion removal. Arabian J Chem 2014;7:174-746.

Received August 16, 2019

Accepted October 14, 2019 